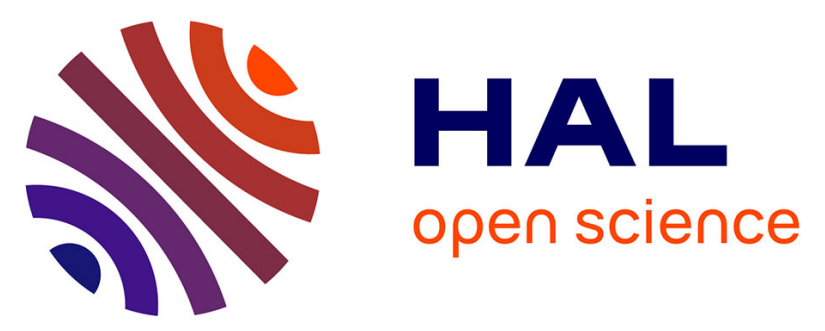

\title{
The World's Smallest Mechanical Parallel Calculator: Discovery of Original Drawings and Patent Documents from the 1950s in Switzerland
}

Herbert Bruderer

\section{- To cite this version:}

Herbert Bruderer. The World's Smallest Mechanical Parallel Calculator: Discovery of Original Drawings and Patent Documents from the 1950s in Switzerland. IFIP International Conference on the History of Computing (HC), May 2016, Brooklyn, NY, United States. pp.186-192, 10.1007/978-3319-49463-0_13. hal-01620132

\section{HAL Id: hal-01620132 \\ https://hal.inria.fr/hal-01620132}

Submitted on 20 Oct 2017

HAL is a multi-disciplinary open access archive for the deposit and dissemination of scientific research documents, whether they are published or not. The documents may come from teaching and research institutions in France or abroad, or from public or private research centers.
L'archive ouverte pluridisciplinaire HAL, est destinée au dépôt et à la diffusion de documents scientifiques de niveau recherche, publiés ou non, émanant des établissements d'enseignement et de recherche français ou étrangers, des laboratoires publics ou privés.

\section{(c)(1)}

Distributed under a Creative Commons Attribution| 4.0 International License 


\title{
The World's Smallest Mechanical Parallel Calculator: Discovery of Original Drawings and Patent Documents from the 1950s in Switzerland
}

\author{
Herbert Bruderer \\ ETH Zurich, Switzerland \\ (brudereraretired.ethz.ch; herbert.bruderer@bluewin.ch)
}

\begin{abstract}
The Austrian engineer Curt Herzstark invented the world-renowned mechanical pocket calculator Curta. The books and the papers on the history of computing mention two models, Curta 1 and Curta 2. In November 2015 original drawings and patent documents on a multiple Curta were discovered in Switzerland. This device is supposed to be the world's smallest mechanical parallel calculator.
\end{abstract}

Keywords: History of computing, pocket-sized mechanical parallel calculator, discovery of drawings and documents on a multiple Curta

\section{Herzstark's Legacy: Discovery of Unknown Machine}

On 14 November 2015 I examined the legacy of Curt Herzstark. It is located at the typewriter museum Beck at Pfäffikon near Zurich. To my great surprise I found original drawings and patent documents of an unknown multiple calculating machine: the world's smallest mechanical parallel calculator.

Curt Herzstark, a highly gifted Austrian engineer, was forced by the Nazis to design the construction drawings for the world-famous Curta at the concentration camp of Buchenwald. The Curta is the smallest and most successful mechanical calculating machine which is able to perform all four basic arithmetic operations. Today, these pretty "pepper mills" are still working. They inspire specialists as well as laymen. From 1947 to 1971 this engineering marvel was produced in large quantities at Mauren (Liechtenstein). Up to now we knew two marks of the stepped drum machine, the Curta 1 and the Curta 2.

According to the patent documents recently turned up any number of mechanical cylindrical calculators may be combined. Herzstark describes the following forms:

- two Curtas side by side,

- two Curtas one upon another,

- four Curtas side by side,

- five Curtas in a circle. 


\section{Characteristic Features of the Multiple Calculating Machine}

The parallel calculator excels in the following properties:

- All machines are driven by one single, common crank.

- All devices may be switched (by axial shifting of the driving shaft) in common or alone to another basic arithmetic operation. This is possible even if the individual machines are set up for different arithmetic operations.

- All registers may be shifted (decade by decade) in common or alone in both rotating directions.

- All result registers and/or revolution counters may be cleared in common or alone.

- The multiple calculation machine can be equipped with an electric drive.

\section{Double, Fourfold and Fivefold Curta}

The extraordinary find proves that the Viennese inventor did not only design single but also multiple Curtas.

\section{Acceleration of the Arithmetic Operations}

The high-precision Curta masters all four elementary arithmetic operations. Thanks to the linkage of several devices computations are considerably speeded up. For instance, if you use a fourfold Curta you input the values 137, 263, 389 and 491. Then you multiply all factors with 7 . The four multiplications are carried out at the same time (with 7 rotations of the crank). The numbers 623, 511, 301 and 259 can be divided by 7 all at once.

Potential applications are the simultaneous conversion of a price list referring to various rates of exchange, the determination of the coordinates $\mathrm{x}$ and $\mathrm{y}$ in surveying at one blow, and computing at the same time the prices by the piece of goods.

\section{The World's Smallest Mechanical Parallel Calculator}

To my knowledge the multiple Curta is the smallest mechanical calculating machine in the world, the first pocket-sized mechanical parallel calculator.

The patent documentation contains comprehensive descriptions. Curt Herzstark presumably built some prototypes. I conducted several oral history interviews with six elderly eye witnesses in Liechtenstein, Austria, Germany and Switzerland. Unfortunately they do not remember the inventor's corresponding research work. The multiple calculating machine was not mass-produced. Herzstark who was defrauded of his lifework by the Nazis had already left his manufacturing firm Contina AG at this time. There is a plans to rebuild the multiple Curta. 


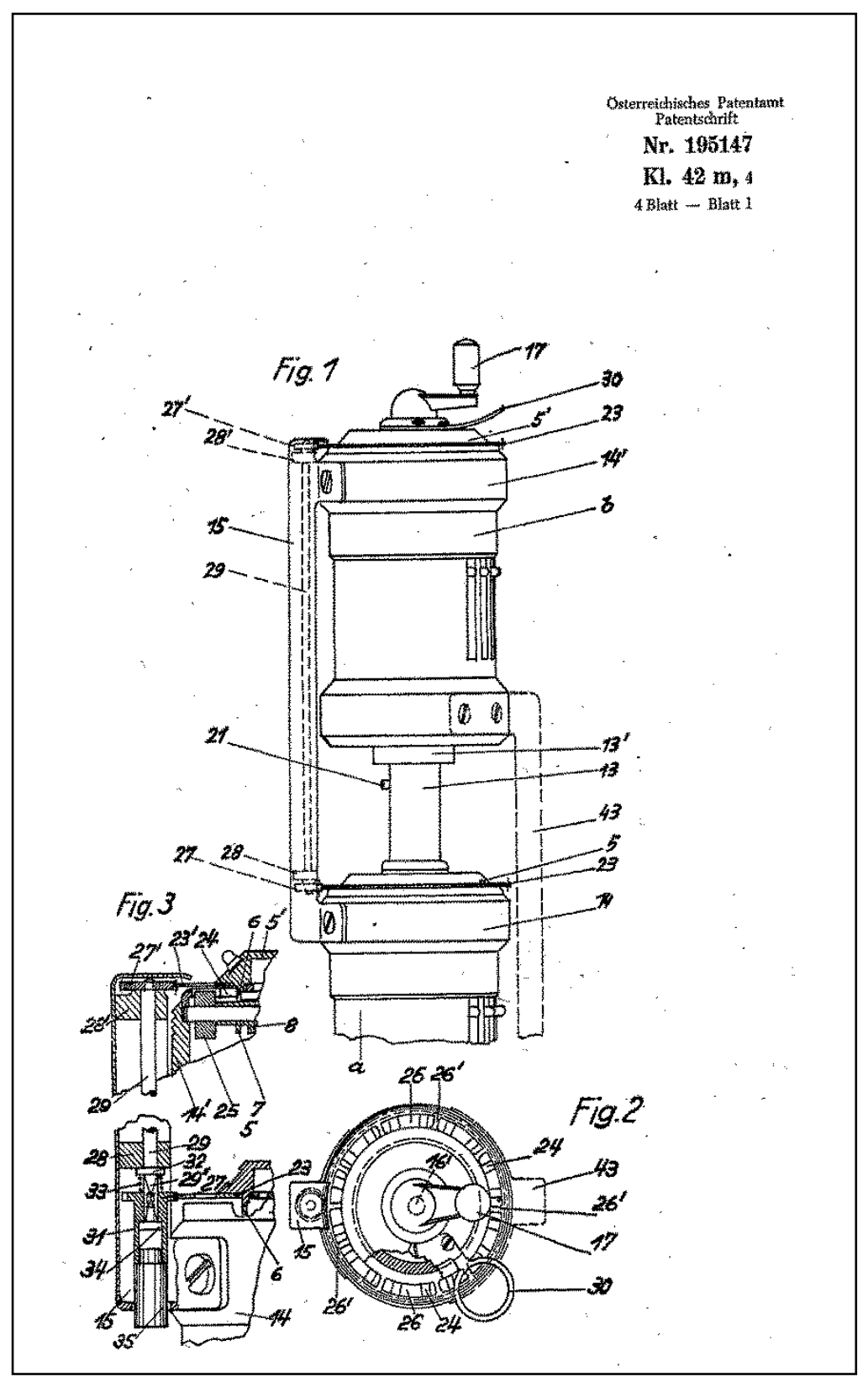

Fig. 1. Double Curta 1. The drawing shows a rigid rod-shaped connection of both machines. According to the patent application more than two devices may be piled up (@) Österreichisches Patentamt, Wien, Stammpatent 1954/57). 
In order to simplify the handling the Austrian engineer designed another type of construction for of the double Curta with a base plate (additional patent).

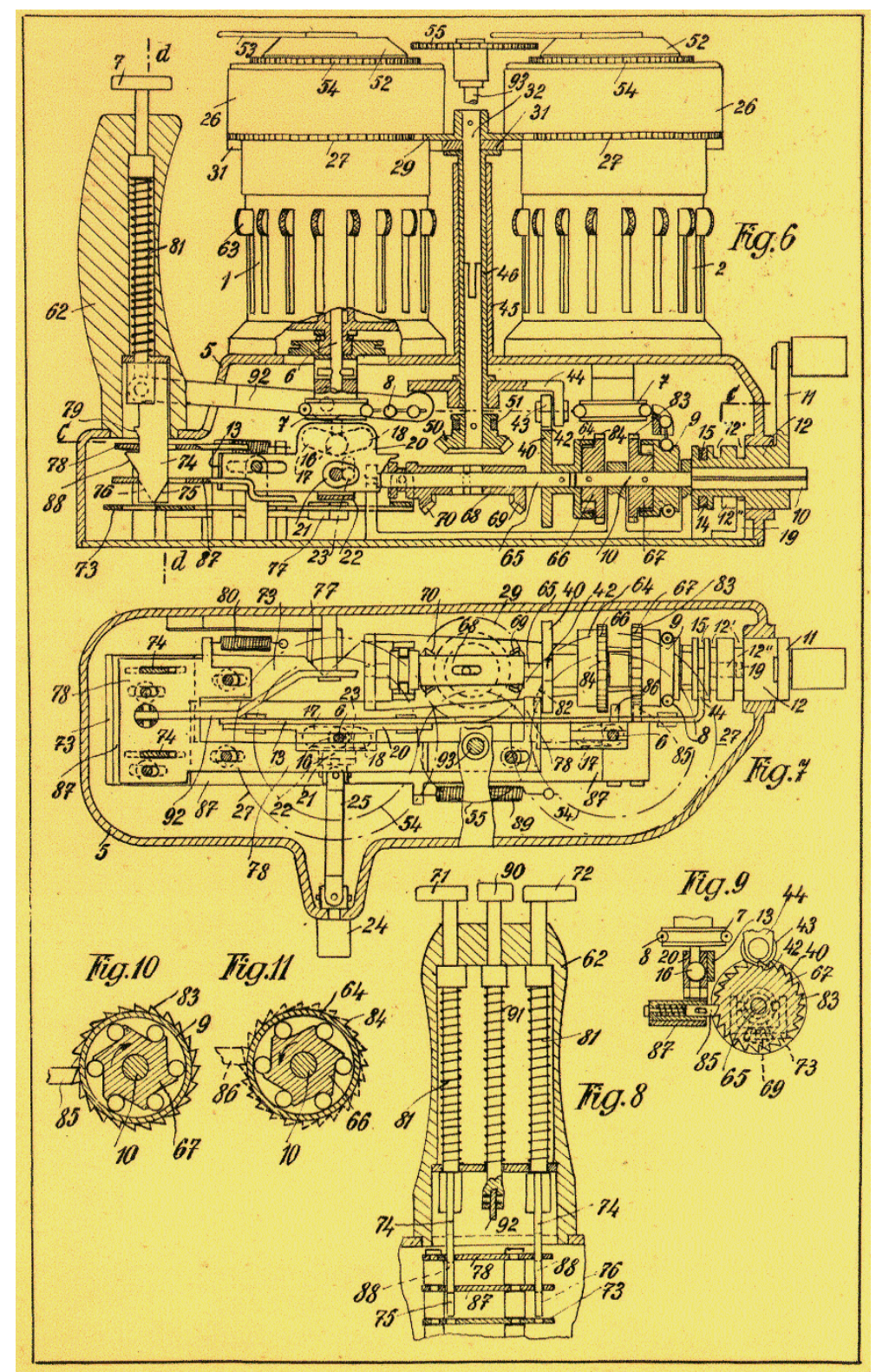

Fig. 2. Double Curta 2. The original drawing presents two mechanical pocket calculators situated side by side. The crank moves the main driving shafts of both devices through bevel and spur wheels. An alternative is a chain drive (@) Schreibmaschinenmuseum Beck, Pfäffikon ZH/Bruderer Informatik, CH-9401 Rorschach 2016). 
The patent application does not mention the following variation with four cylindrical machines.

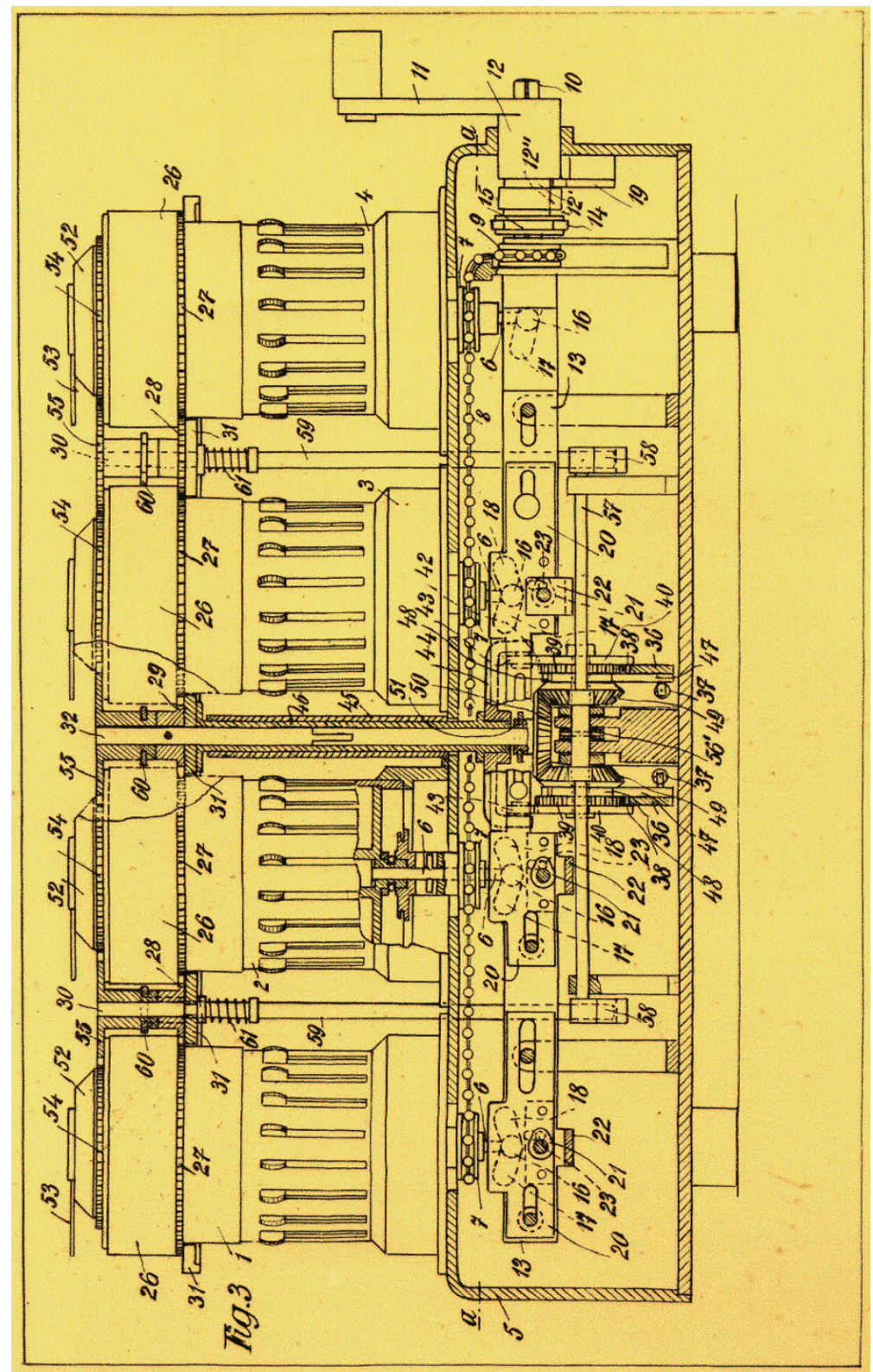

Fig. 3. Fourfold Curta. This original drawing depicts four removable Curtas mounted on a pedestal. The latter is provided with coupling, drive and control organs. The common crank is connected to the stepped drum shafts by a chain drive (@ Schreibmaschinenmuseum Beck, Pfäffikon ZH/Bruderer Informatik, CH-9401 Rorschach 2016). 


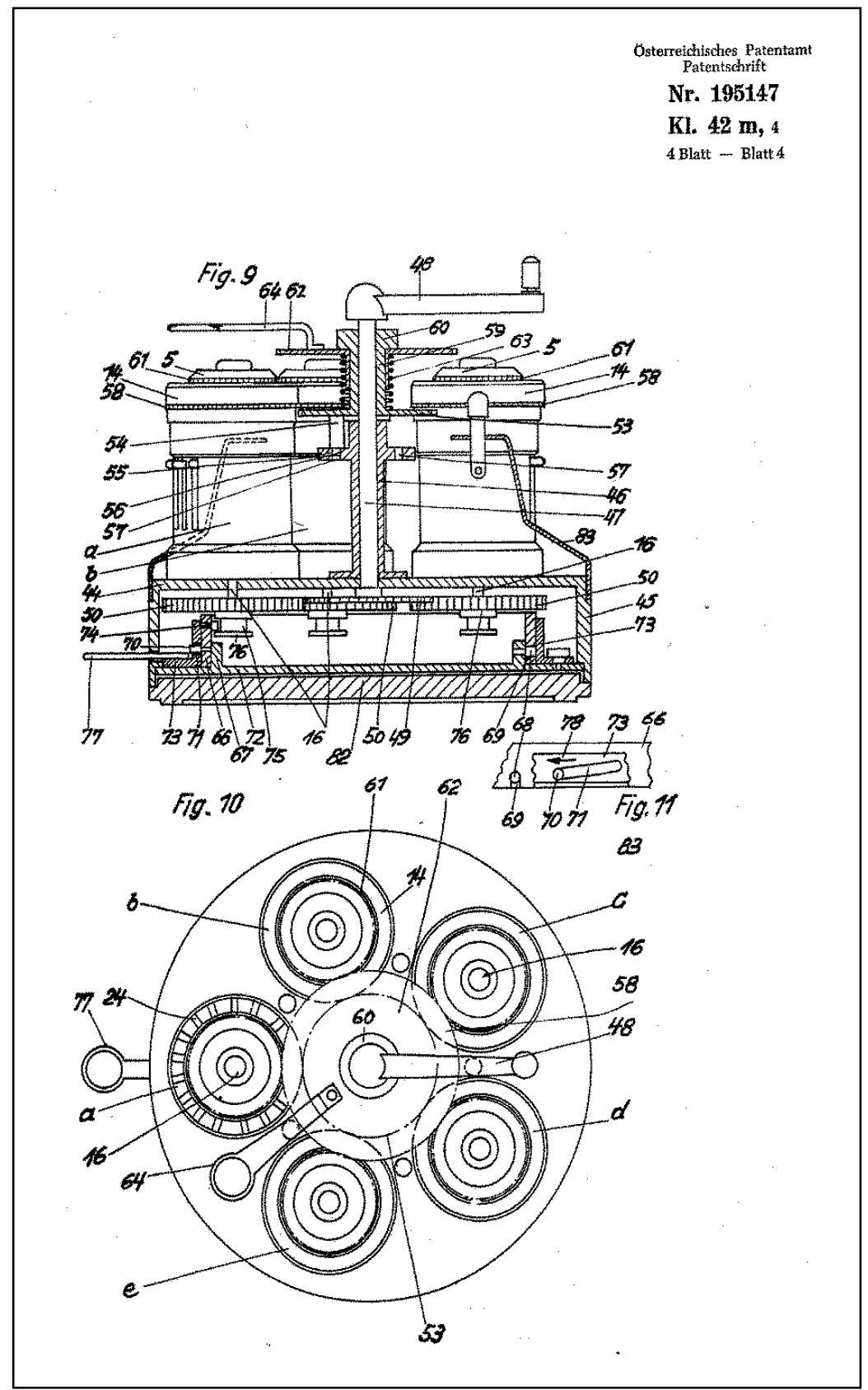

Fig. 4. Fivefold Curta. The five pocket calculating machines stand on a revolving pedestal which is attached on a circular base plate. Thus the setting mechanisms of the five devices can be comfortably manipulated. The principal driving shaft (in the middle) with the crank is connected through spur wheels with the five stepped drum shafts (@ Österreichisches Patentamt, Wien, Stammpatent 1954/57). 
Acknowledgment. The author is very grateful to Stefan Beck from the typewriter museum in Pfäffikon near Zurich.

\section{End Notes}

Original drawings and patent documents of Curt Herzstark, Schreibmaschinenmuseum Beck, Pfäffikon ZH, and European patent office, Munich (database). There are the following Austrian patent specifications concerning Curt Herzstark's multiple calculating machines:

- Patentschrift Nr. 195147 (25 January 1958, basic patent):

patent application (19 October 1954),

patent grant (15 May 1957),

- Patentschrift Nr. 205775 (10 October 1959, additional patent):

patent application (15 December 1954),

patent grant (15 March 1959).

The first Austrian patent application for the multiple calculator already stems from 20

December 1949. There were also preparations for an US patent. Former Austrian patents about the conventional Curta bear the following numbers 747 073/192, 747 074/191, 166 581, 163 380 .

- Bruderer, H.: Meilensteine der Rechentechnik. Zur Geschichte der Mathematik und der Informatik (Milestones in Analog and Digital Computing. Contributions to the History of Mathematics and Information Technology), de Gruyter, Berlin/Boston 2015, 850 pages

- Bruderer, H.: Multiple Curtas, in: CBI Newsletter, Spring 2016, pages 21-23

- Bruderer, H.: Computing History outside UK and USA: some selected Landmarks from Continental Europe, in: Communications of the ACM (forthcoming). 